植物葉分光スペクトル特性におよぼす

\author{
カロテノイド組成の影響
}

吉村晴佳

\title{
Spectral Properties of Leaves \\ Affected by Carotenoid Components
}

\author{
YosHimuRA, Haruka
}

\begin{abstract}
要旨
植物葉分光スペクトル特性と光合成機能に必要なカロテノイド組成の影響について, 薄 層クロマトグラフィ(TLC) による定性組成から述べ，その応用展開の技術にも言及した。 5 樹種の緑葉で共通に, カロテン類, ルテイン, ヴィオラキサンチン, ネオキサンチンが認 められ, 高等植物の主要なカロテノイド組成の共通性が確認された。黄葉・紅葉ではカロ テノイド量の減少とともにその組成は変動し, カロテノイド組成の環境応答的な変動が示 唆された。可視・青領域は, 緑葉, 秋季の黄葉・紅葉さらには枯葉でもカロテノイド類が 関与する吸収域である。青領域の低い反射特性の共通性は，今後リモートセンシング植生 域解析において, 気候帯, 植物群落夕イプあるいは季節変化に関わらない地表被覆情報と して利用できうる。光合成活性指標としてのキサントフィル・サイクル色素は, カロテノ イド組成変換に伴う吸収域シフトのスペクトル変化が遠隔探知されるというメカニズムで ある。植物葉の青領域分光スペクトル特性を空間設計の基礎デー夕として考えると，スペ クトル特性をいかした緑化設計により私たちの健康にマイナスの影響を与える過剩な青色 光の光環境緩和ができる。
\end{abstract}

\section{1. はじめに}

1997 年に採択された京都議定書では温室効果ガ 又吸収源として森林植生および森林土壤が認められ た。地質学的な時間から考えると現在の光合成は大 気の $\mathrm{CO}_{2}$ および $\mathrm{O}_{2}$ が制限要因となっており，植物 群はきわめて有効な環境応答型の調節機構となりう るとの考えもある ${ }^{12)}$ 。温室効果ガス削減問題と関連

キーワード：葉分光反射スペクトル,カロテノイド組成, 薄層クロマトグラフィ, 秋季紅葉現象, キサントフィル・ サイクル色素, 空間設計

Key words : Leaf reflectance, Carotenoid components, Thin-layer chromatography, Autumn senescence, The xanthophyll cycle pigments, Spatial planning
して，緑化分野においても二酸化炭素吸収源の計測 技術が求められている。その二酸化炭素吸収源とし ての植物の光合成活性を計る主要な植生パラメータ の一つとしてキサントフィル・サイクル色素（xanthophyll cycle pigments）があがっている14)。この 計測技術には，その基礎として，植物の光合成機能 に必要なカロテノイド組成が関与する分光スペクト ルに関する知識が必要である。

カロテノイド類 (carotenoids) は, 図 1 に示すよ うに，(1）酸素を含まない炭化水素であるカロテン 類 (carotenes) と（2）さまざまな形で酸素を含むキ サントフィル類 (xanthophylls) に分類されてい $3^{5,11)}$ 。光合成活性のある植物組織に含まれている光 合成機能に必要なカロテノイドは第一義カロテノイ 


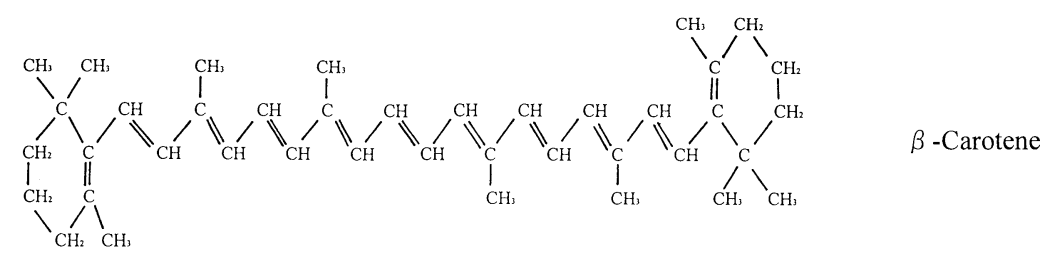

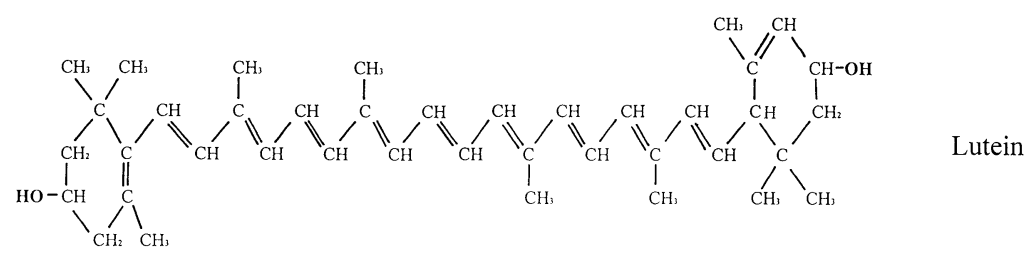

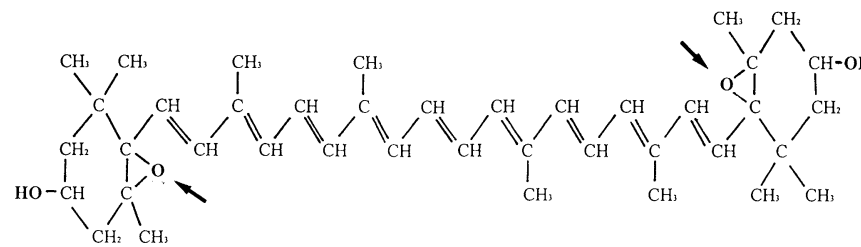
Violaxanthin

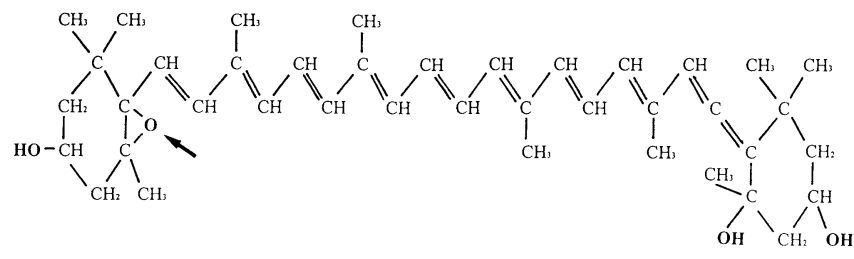
Neoxanthin

図 1 高等植物の主要なカロテノイドの構造式5,6,11)。エポキシ（epoxy）を矢印で，ヒドロキシ（hydroxy）をゴシック 字体で示した。

Fig. 1 Chemical structure of the main chloroplast carotenoids of higher plants. Small arrows indicate the epoxy groups and Gothic :cript shows the hydroxy groups. ${ }^{5,6,11)}$

ド（primary carotenoids），黄色から赤を示す果実 や花のカロテノイドは第二義カロテノイド (secondary carotenoids）とよばれている11)。図 2 に示すよ うに緑葉, 落葉広葉樹の黄葉・紅葉にかかわらず, 分光スペクトルにおいて, カロテノイドは可視・青 領域の吸収要因となっている ${ }^{18,20)}$ 。

この報告は，植物葉分光スペクトル特性におよぼ すカロテノイド組成の影響について，光合成活性の ある緑葉および秋季の黄葉・紅葉の薄層クロマトグ ラフィ（TLC）により得られた定性組成から述べる。 さらに, その応用展開の技術として, リモートセン シング植生域解析での特性利用について論じ, 光合 成活性計測技術としてのキサントフィル・サイクル 色素の遠隔探知のメカニズムについても記述する。 また, 緑化の機能の視点から, カロテノイドが関与
する領域の分光スペクトル特性を空間設計の基礎デ ータとして考えた場合，スペクトル特性をいかした 緑化設計により，私たちの健康に有害な作用をおよ ぼしている過剒な青色光の光環境の緩和ができるこ とについても言及する。

\section{2. 材料および方法}

\section{1 材料}

試料は, 暖温帯樹種より落葉広葉樹で秋季に黄葉 するエノキ (Celtis sinensis Persoon), 紅葉するイ ロハモミジ (Acer palmatum Thunb.), 常緑広葉樹 のコジイ (Castanopsis cuspidata (Thunberg) Schottky) およびタブノキ(Persea Thunbergii (Sieb. et Zucc.) Kostermans), 常緑針葉樹のスギ (Cryptomeria japonica (L.f.) D. Don) の 5 種とし, 


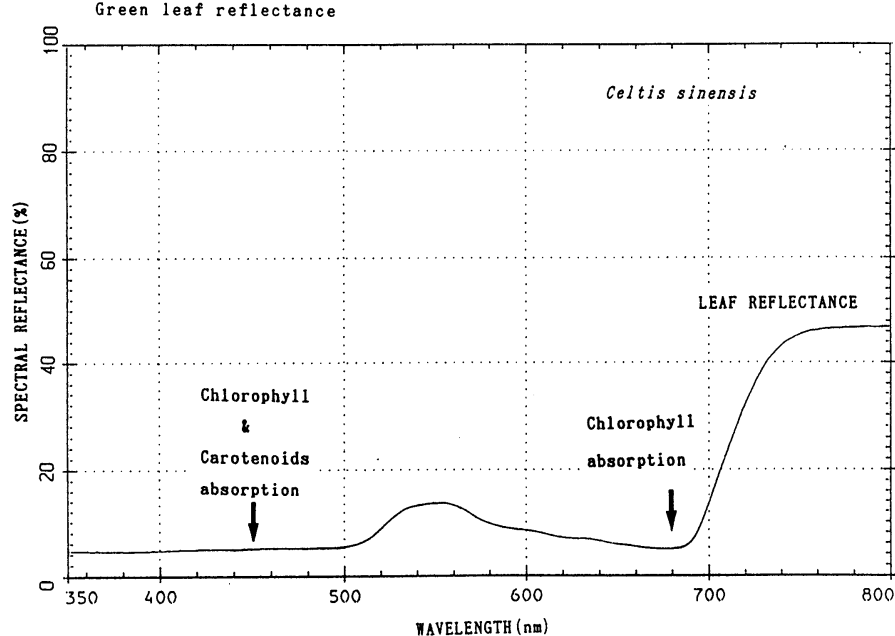

Yellow leaf reflectance with autumn senescence

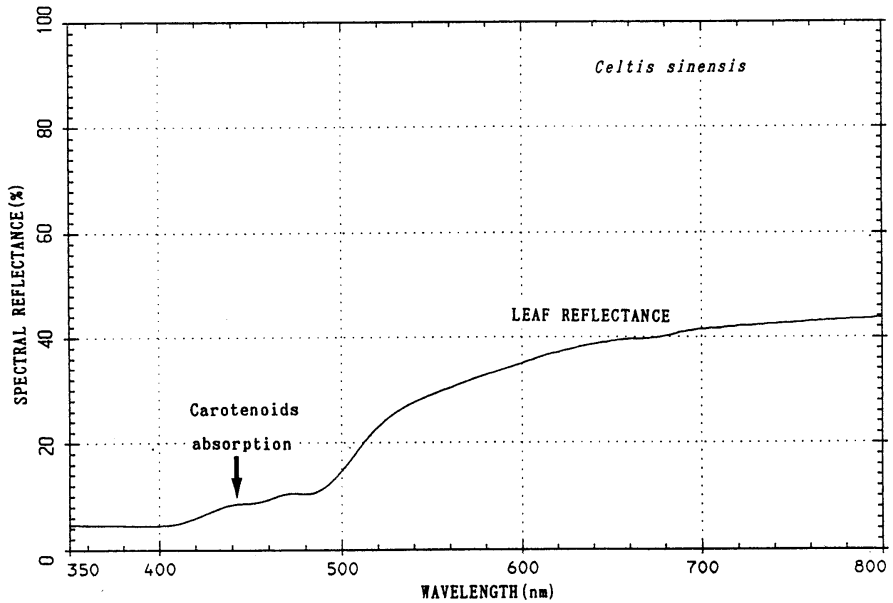

Red leaf reflectance with autumn senescence

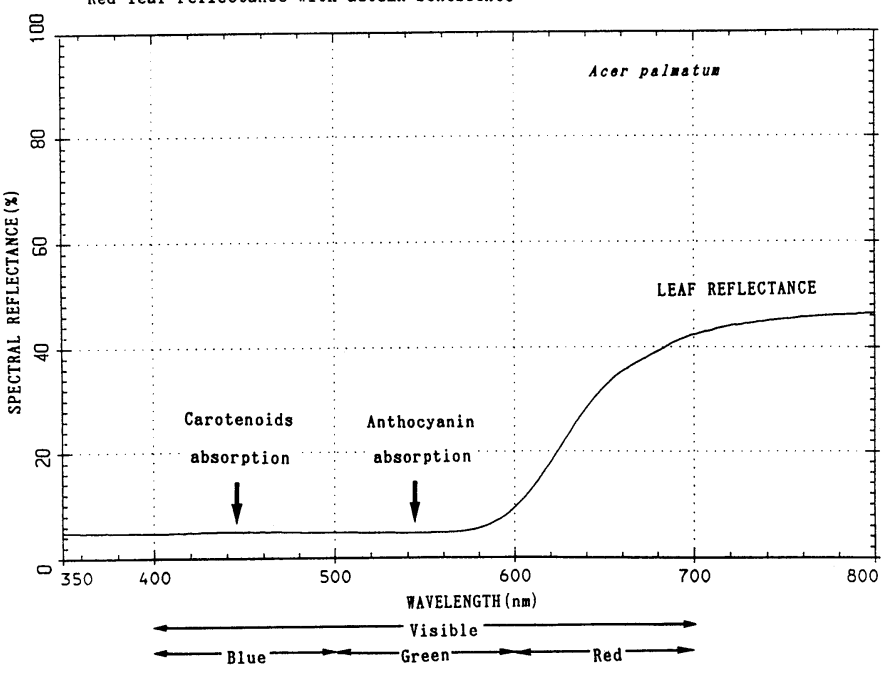

図 2 カロテノイドが緑葉および秋季の黄 葉・紅葉の分光スペクトル特性におよ ぼす影響。緑葉の可視・青領域の低い反 射はクロロフィルとカロテノイドによ る。秋季の黄葉・紅葉では残存するカロ テノイドにより可視・青領域の反射は 低い ${ }^{18,20)}$ 。

Fig. 2 Leaf reflectance with various physiological states. The low reflectance of photosynthetically active green leaf in the visible blue region is caused by chlorophylls and carotenoids. Yellow leaves and red leaves with autumn senescence show low reflectance in the visible blue region affected by remaining carotenoids. ${ }^{18,20)}$ 
試料木として京都府立大学構内と京都府立植物園の 樹高 $3 \mathrm{~m}$ 以上の林分構成個体を選定した。同一個体 の南向きの陽葉部分（常緑樹種については当年葉） を，高枝切りで枝ごと午前中に採取した。採取した 枝は，アイスボックスに入れて研究室に持ち帰り, 直ちに色素の抽出に供した。試料は緑葉期について は 1990 年 9 月 21 日, 紅葉時については同年 11 月 21 日, 枯葉については冬季の林床から乾燥状態の当 年落葉を 1995 年 2 月 23 日に採取した。

\section{2 方法}

2.2.1 樹葉の分光反射スペクトル測定方法

分光光度計 (島津製作所製, UV-2100)の内部に積 分球付属装置(島津製作所製, ISR-260) を装着して, $350 \sim 800 \mathrm{~nm}$ の波長域について $0.2 \mathrm{~nm}$ 間隔で単葉 の分光反射スペクトルを測定した。

\subsection{2 クロロフィルとカロテノイドの抽出方法}

葉色素の抽出は SANGER ${ }^{15)}$ の方法にしたがい, 基 本的に暗条件下で行った。採取した樹葉はそれぞれ 正確に $5 \mathrm{~g}$ を計量し, 細断し, 少量 $(25 \mathrm{ml})$ の $90 \%$ 冷アセトン $\left(-15^{\circ} \mathrm{C}\right)$ とともに, $1 \mathrm{~g}$ の $\mathrm{MgCO}_{3}$ を加 え, ワーリングブレンダーで粉砕し, ガラスフィル ターを用いて減圧吸引濾過した。残渣はアセトンで 再抽出し, 同様の手順を 3 回繰り返し最終体積を $200 \mathrm{ml}$ にした。このアセトン抽出液にはクロロフィ ルとカロテノイドが含まれている。

2.2.3 アセトン抽出液からの総カロテノイド抽 出方法

以下の SANGER ${ }^{15)}$ の方法にしたがい, アセトン抽 出溶液に含まれているクロロフィルをケン化・転溶 処理により取り除き, 総カロテノイド抽出溶液を得 た。アセトン抽出液のうち $25 \mathrm{ml}$ に, 同量の $20 \%$ メ タノール性 $\mathrm{KOH}$ を加えラップで覆い, 暗室下室温 で 2 時間ケン化を行った。その後，カロテノイドを 分液ロートを用いて, 石油エーテル (沸点 $30 \sim 60^{\circ} \mathrm{C}$ ) に転溶させ抽出し，この石油エーテル溶液を蒸留水 で洗浄し, 無水 $\mathrm{Na}_{2} \mathrm{SO}_{4}$ で乾燥させた後, 総力ロテ ノイド抽出溶液を得た。

2.2.4 総カロテノイド抽出溶液の吸光度スペク トル測定方法

自記分光光度計 (島津製作所製, UV-2100)により, $10 \mathrm{~mm}$ 石英セルに入れた総カロテノイド抽出石油 エーテル溶液について, 石油エーテルを対照として 吸光度スペクトルを測定した。

\section{2 .5 薄層クロマトグラフィによるカロテノイ ド類分離方法}

上記の方法で得られたアセトン抽出液およびカロ テノイド抽出石油エーテル溶液を, 必要に応じてエ バポレーターで濃縮し, 点着試料とした。市販のシ リカ TLCプレート (Whatman PLK5F) に試料を スポットし，ドライアーで完全に乾燥させて展開槽 に入れた。なお, Whatman PLK5F $(20 \mathrm{~cm} \times 20 \mathrm{~cm})$ の下部には $3.5 \times 20.0 \mathrm{~cm}$ の前吸着・点着領域 (preadsorbent spotting area) が設定されており, スタートが一致し, 試料は水平に分離する。

展開溶媒は, 似かよった酸素加反応 (oxygenate) をしているカロテノイドを識別するための分離力の 優れた FRANCIS and ISAKSEN (1988) ${ }^{2)}$ の方法, 石油 エーテル (petroleum ether, 沸点 $40 \sim 60^{\circ} \mathrm{C}$ ) : 第三 ブタノール $($ tert-butanol $)=80: 20(\mathrm{v} / \mathrm{v}$ percent $)$, を選択した。展開は, 展開槽が溶媒気体で満たされ るように注意し, 室温, 暗条件下で行った。色素の 種類は, 5 樹種の緑葉, 秋季のエノキの黄葉, 紅葉の イロ八モミジについて，定法2,5,6)にしたがい，薄層 クロマトグラム上の $R_{F}$ 值 (展開物質の移動距離/溶 媒の始点から先端までの移動距離 $\times 100)$ 抢よび色調 から同定した。

\section{3. 結果および考察}

3.1 緑葉の総カロテノイド吸光度スペクトル 図 3 に 5 樹種の緑葉の総カロテノイド抽出石油工 ーテル溶液の吸光度スペクトルを示した。5 樹種の 全てで, 可視・青領域 $(400 \sim 500 \mathrm{~nm})$ が吸収領域で, 主要な吸収ピークが $450 \mathrm{~nm}$ 付近にあり, その両側 に二つの吸収ピークがあるカロテノイドに特徴的な 吸収スペクトルを示した。吸収スペクトルの波形が 非常に似かよっていることから，樹種による組成の 差異は極めて少ないと考えられた。

\section{2 緑葉の TLC}

図 4 亿光合成活性のある 5 樹種の緑葉カロテノイ ド類の薄層クロマトグラムを示した。 5 樹種の緑葉 に共通に, カロテン類(carotenes), およびキサント フィル類のルテイン (lutein), ヴィオラキサンチン (violaxanthin), およびネオキサンチン (neoxanthin）が確認された。カロチン類とルテインは橙黄 色，ヴィオラキサンチンは黄色，ネオキサンチンは 淡黄色を示した。

これまでの報告では, 高等植物の緑葉に含まれる 


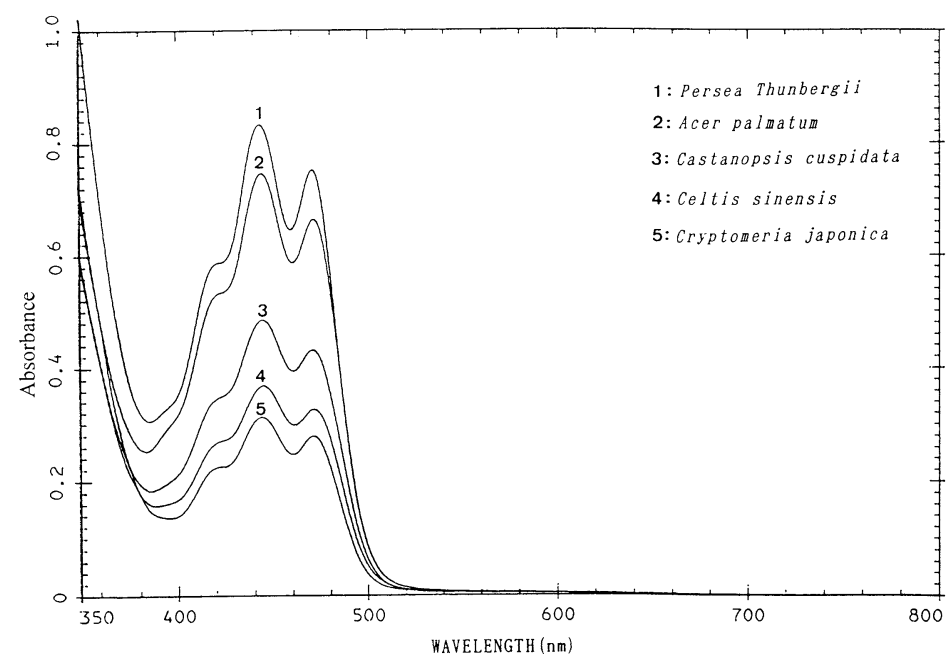

図 35 樹種の緑葉から抽出した総カロテノイドの吸光度スペクトル

(対照：石油エーテル, 光路長 : $10 \mathrm{~mm}$ )

Fig. 3 Absorption spectrum of total carotenoids extracted from green leaves of five different tree species (Reference: petroleum ether, Pathlength: $10 \mathrm{~mm}$ )

カロテノイド類は， $\beta$-カロテン，ルテイン，ヴィオ ラキサンチン，打よびネオキサンチンが共通であ $\eta^{1,4,5,8,9,10,13,15,16)}$, その他に $\alpha^{-カ ロ ロ テ ン ~}{ }^{5,8,9)}$, クリプ トキサンチン (cryptoxanthin) ${ }^{5)}$, ゼアキサンチン (zeaxanthin) ${ }^{5,9)}$, アンテラキサンチン (antheraxanthin) ${ }^{1,9,10)}$ が認められている場合もある。樹種の 異なる本報告の TLCの結果からも, 高等植物の力 ロテノイドの主要な組成の共通性が確認された。

3.3 秋季の黄葉・紅葉の総カロテノイド吸光度 スペクトル

図 5 にクロロフィルがほぼ完全に分解された状態 の黄葉のエノキ, 紅葉のイロハモミジの総カロテノ イド石油エーテル溶液の吸光度スペクトルを示し た。両者ともに黄色カロテノイドに典型的な吸収ス ペクトルを示したが, 緑葉の総カロテノイドと比較 し，総力口テノイド量が減少しているにもかかわら ず，長波長がわの吸収の端の部分（ショルダー： shoulder）の $500 \mathrm{~nm}$ あたりに上昇のシフトが認め られ, 組成の変化を示唆していた。

3.4 黄葉・紅葉の TLC

黄葉のエノキ・紅葉のイロハモミジに残存するカ ロテノイドの薄層クロマトグラムを図 6 に示した。 破線はトレース（trace）を示す。黄葉・紅葉ともに， 橙黄色のカロチン類, ルテインが明瞭に確認され, 黄色のヴィオラキサンチン, および淡黄色のネオキ
サンチンがわずかに認められた。この結果は，樹種 が異なる SANGER ${ }^{15)}$ によるぺーパークロマトグラフ イの結果と同様であり, 黄葉・紅葉の植物生理学的 変化により, カロテノイドの量の減少とともに組成 も変動することが示された。これは, 植物葉のカ口 テノイド組成が環境応答的に生理生態的な変化をす る一例と考えられた。

\section{4. カロテノイド組成が関与する分光スペクトル 特性の応用技術}

枯葉についてもカロテノイドは残存するという報 告 ${ }^{15)} も$ あ, 図 7 に示すように, 枯葉における可 視・青領域についても，樹種によらず残存するカ口 テノイドによると考えられる吸収領域で反射は低 い。図 8 にまとめたように, 植物葉の分光スペクト ルに扔いて, 緑葉, 黄葉・紅葉さらには枯葉につい ても, 可視・青領域はカロテノイドが関与する吸収 領域である。植物葉の, 紫外域 ${ }^{17)}$ に続く可視・青領 域の低い反射特性は, 植物の種にかかわらず，また， 季節変化も少ない特性である。したがって, 今後基 礎データの充実およびリモートセンシングデータと のフィードバックの必要があるが，リモートセンシ ングによる植生域解析において, 気候帯, 植物群落 タイプあるいは季節変化にかかわらない植物の同化 組織と同化組織に由来する地表被覆の共通特性とし 

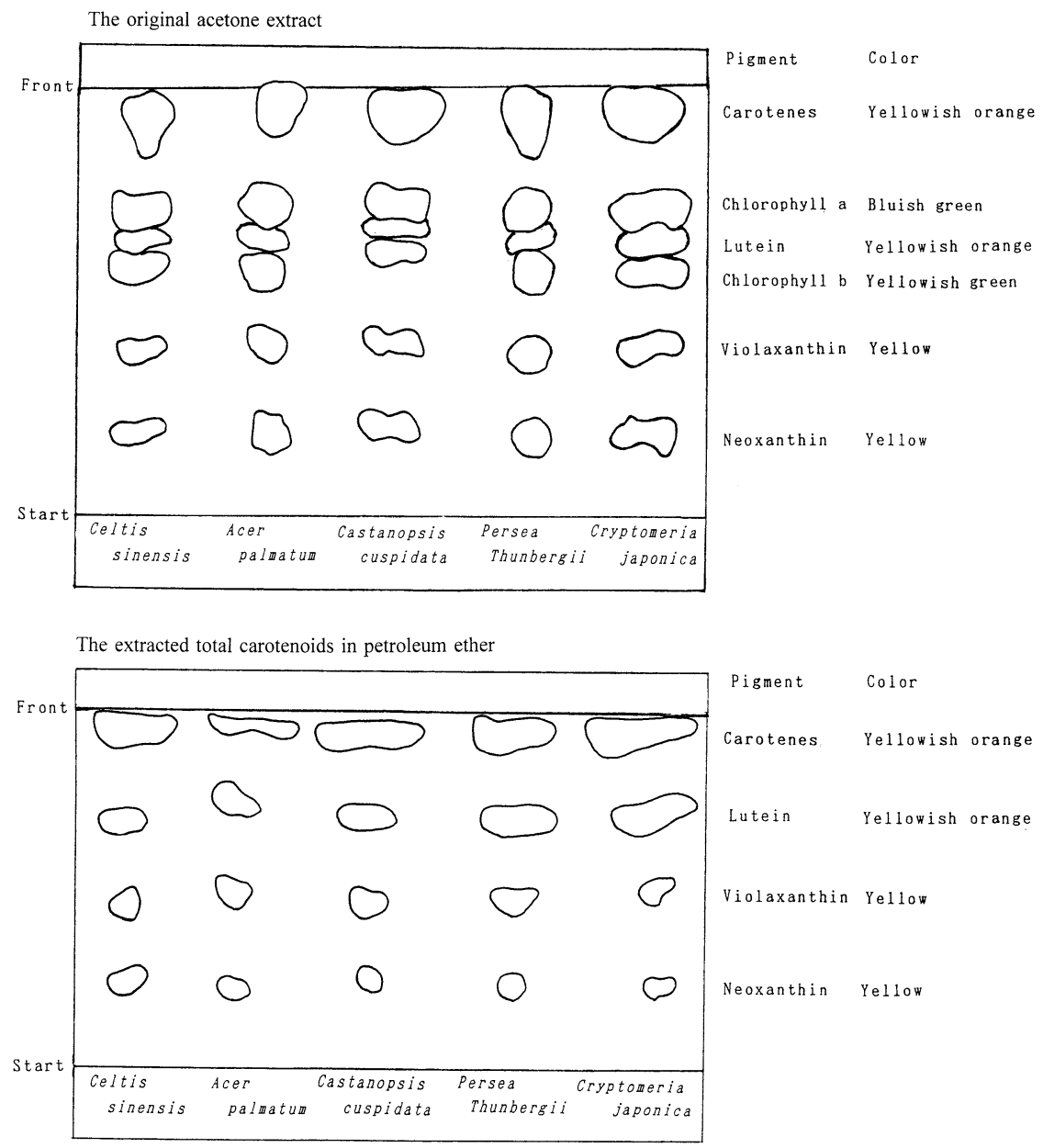

図 45 樹種の緑葉から抽出した色素の薄層クロマトグラム。光合成活性のある緑葉では主要なカロテノイド組成として カロテン類，ルテイン，ヴィオラキサンチン，ネオキサンチンを含む5,11)。

Fig. 4 Thin-layer chromatograms of pigments extracted from green leaves of five different tree species. Photosynthetically active green leaves include carotenes, lutein, violaxanthin, and neoxanthin as major components. ${ }^{5,11}$

て利用できる可能性がある。

カロテノイド組成変化にともなう分光反射スペク トル変化を応用する技術として，植生パラメータの キサントフィル・サイクル色素がある。光合成活性 のある植物だけの特性として, 光合成活性指標とな るとされている“キサントフィル・サイクル色素の 転換”が知られている。キサントフィルのヴィオラ キサンチンは，吸収した光合成有効放射（photosynthetically active radiation: PAR) が光合成 反応の能力をこえるような過剰な強光条件下では, アンテラキサンチンを経てゼアキサンチンへと転換 していく ${ }^{3,7,11)}$ 。この反応は, 光量を制限すると容易に
逆方向にもどっていく ${ }^{3)}$ 。この生化学的な組成転換 にともなうエポキシ化の状態によって，キサントフ イル・サイクル色素の吸収域全体はシフトする。可 視・青領域はクロロフィルおよびカロテノイドの吸 収が重なりあった領域であるために，吸収極大のシ フトは捉えることができない。しかし，可視・緑領 域にあるキサントフィル・サイクル色素吸収のショ ルダーのシフトについては，エポキシ化の異なる状 態の植物葉反射スペクトルについて差スペクトルを 求めると, その差分が $531 \mathrm{~nm}$ 付近をピークとして あらわれる31，というものである。この $531 \mathrm{~nm}$ 付近 のシグナルは植物生理学の理論に基づいて探知さ 


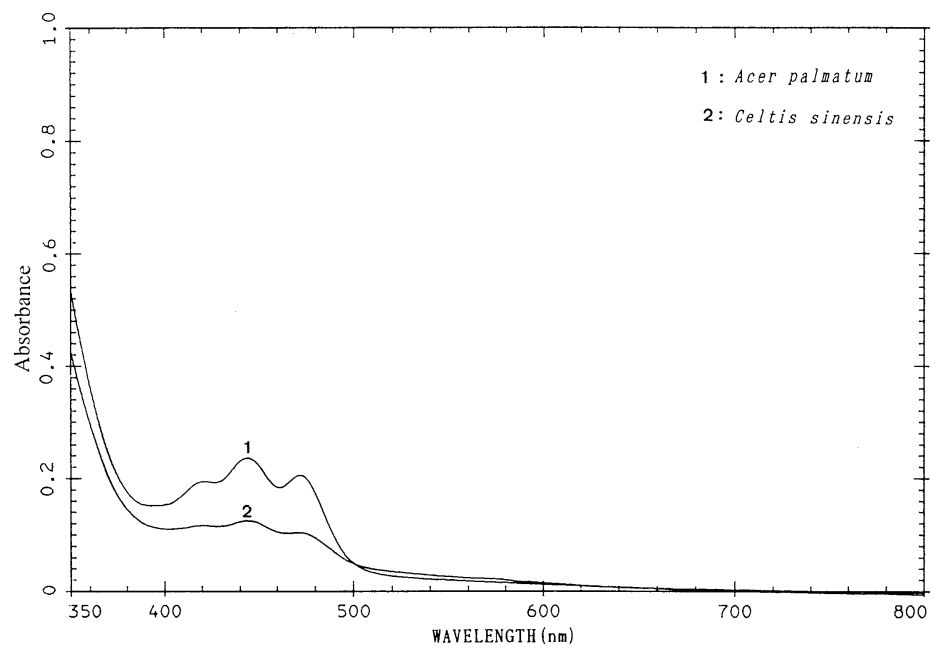

図 5 秋季の黄葉・紅葉から抽出した総カロテノイドの吸光度スペクトル

(対照：石油エーテル, 光路長：10 mm)

Fig. 5 Absorption spectrum of total carotenoids extracted from yellow leaves and red leaves with autumn senescence (Reference: petroleum ether, Pathlength: $10 \mathrm{~mm}$ )

The original acetone extract

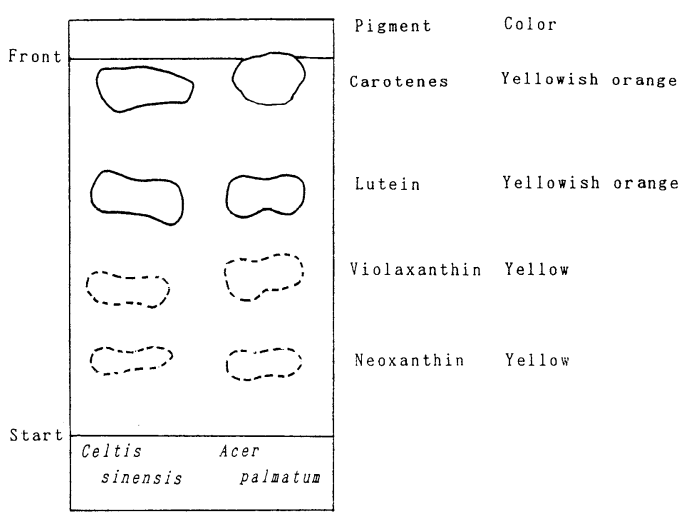

The extracted total carotenoids in petroleum ether

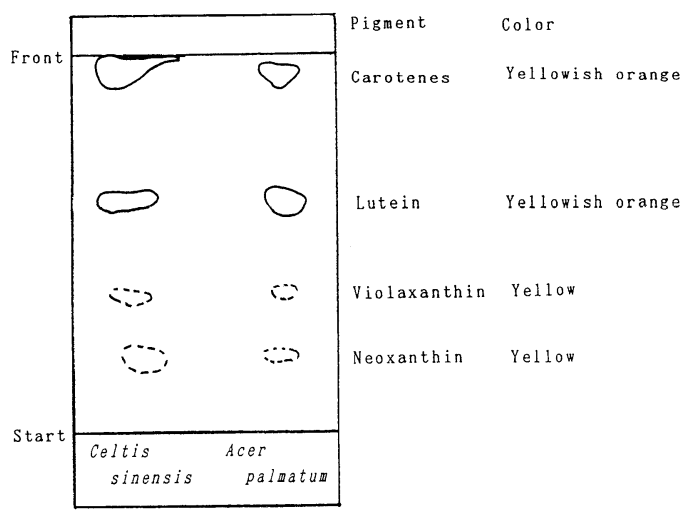

図 6 秋季の黄葉・紅葉から抽出した色素の薄層クロマトグラム

Fig. 6 Thin-layer chromatograms of pigments extracted from yellow leaves and red leaves with autumn senescence. Carotenes and lutein were observed with traces of violaxanthin and neoxanthin.

れ, しかもこの変換は光合成活性の指標となること から, 植物の光合成効率 (photosynthetic efficiency) のパラメータとして研究がすすめられている ${ }^{3)}$ 。光 合成研究でキサントフィル・サイクルは1970 年代か ら知られている現象で3,7,11), リモートセンシングの 分光スペクトル解析によって捉える試みは 1990 年

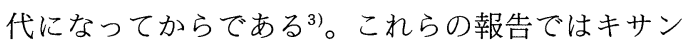
トフィル・サイクル色素のエポキシ化状態の定量に は高速液体クロマトグラフィ（HPLC）、が用いられ
ており，これまで葉重量あたりで求めることが多か った色素量は，葉面積あたりで扱われている。

また, 植物葉のカロテノイドが関与する可視・青 領域特性を光環境空間設計の基礎データとして考え ると, 植物葉スペクトル特性をいかした植物の設計 と運営により, 過剩な青色光環境の緩和という機能 を創出できる ${ }^{17,19)}$ 。

光環境は，世代を超えて私たちの健康に大きく影 響をおよぼす。たとえば，紫外線の過剰な被曝は， 


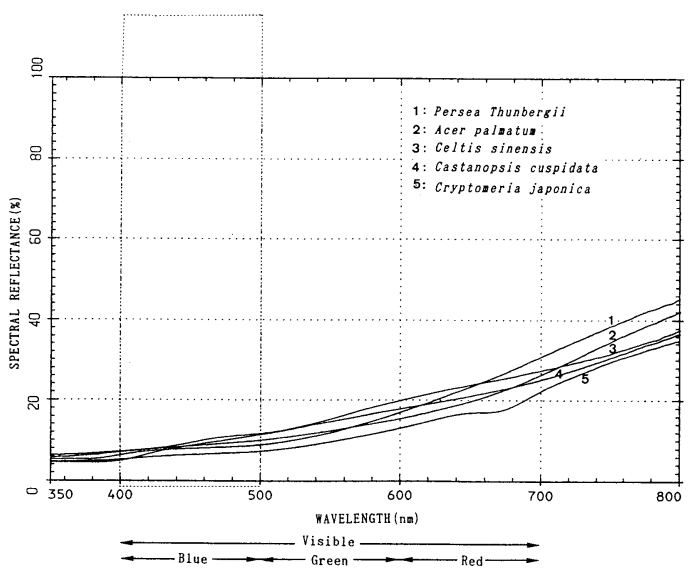

図 75 樹種の枯葉の可視域分光反射スペクトル。樹種 にかかわらず，青領域の反射は低い。

Fig. 7 Spectral reflectance in the visible region of dead leaves of five different tree species. Reflectance in the blue region was low.

皮膚ガン，アトピー性皮膚炎の要因となり，身体全 体の免疫力（私たちの身体自身が持ってるガンや病 原菌を抑える機能）を低下させる。世界的に社会問 題となっている白内障は，眼の入りロでレンズの役 割をしている水晶体が白濁するもので失明する場合 もあり, 紫外線はその要因である。紫外線のみなら ず，紫外域に近い可視・青領域の光も，私たちの眼 球後方の網膜を構成している光を感じる細胞である 視細胞に非可逆的な傷害を引き起こし，加齢性網膜 色素変性症の要因とされている。このような網膜の 損傷・変性によっても, 視覚は著しく劣化し, 失明 に至る場合もある。植物葉は可視・青領域光をカ口 テノイド類などにより選択的に吸収している。植物 葉を透過した光は可視・青領域の光が著しく減少す る。植物葉を反射した光についても青色光は減少す る。しかも，この特性は，芽吹きから夏の緑葉，秋 の黄葉·紅葉においても季節変化は少なく,さらに, 冬季の落葉についてもこの特性を失っていない。し たがって，このような特性をいかした植物の設計と

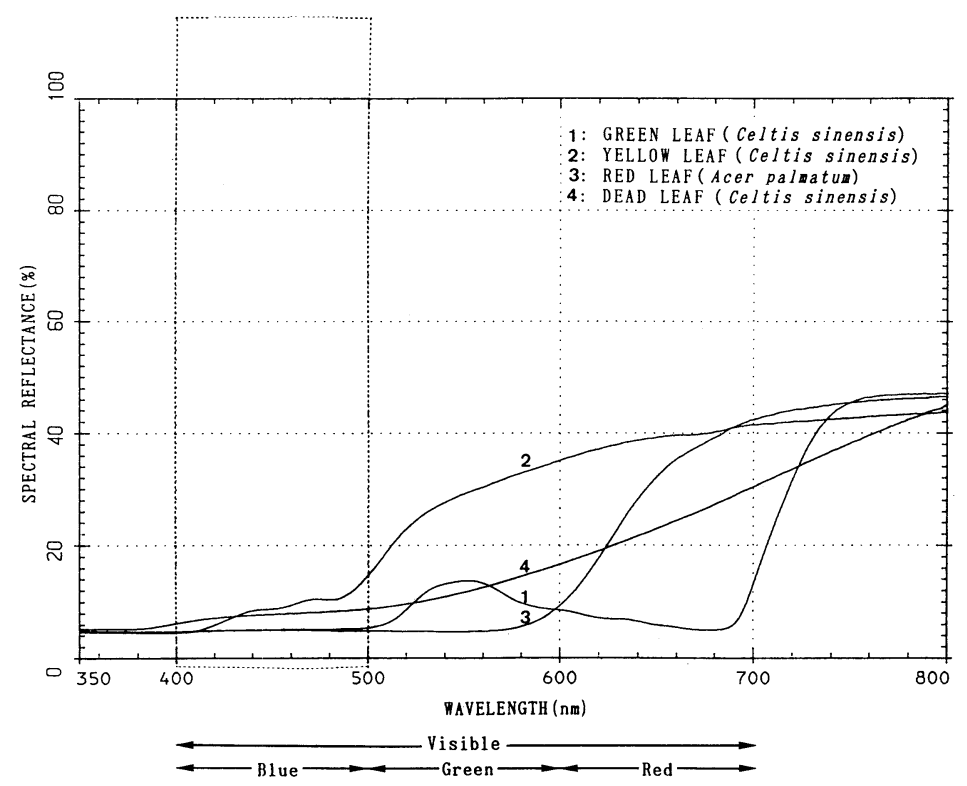

図 8 カロテノイドにより緑葉, 黄葉・紅葉さらには枯葉でも可視・青領域の反射は低い。しかし, 光合成活性のある植 物でのみ, 強光下でキサントフィル・サイクル色素の変換により組成が変動し，その吸収域のシフトによる分光ス ペクトル変化は差スペクトルで遠隔探知できる3)。

Fig. 8 Reflectance in the visible blue region with various physiological states of leaves, photosynthetically active green, autumn senescence and falling dead, is low by absorption of carotenoids. Only in photosynthetically active leaves excessive absorbed light causes deepoxidation of the xanthophyll violaxanthin. The difference spectrum associated with conversions of the xanthophyll cycle pigments results in a detectable shift in the leaf reflectance. ${ }^{3)}$ 
運営により, 労働空間, 居住空間, 教育空間の青色 光の光環境を緩和することができる。このような空 間計画にあたっては, 熱環境の緩和, 景観, 有機的 な水の浄化・循環利用, 温暖化ガス $\mathrm{CO}_{2}$ 固定といっ た機能とともに，季節性などさまざまで多様な植物 素材のそれぞれの特性をいかして, 光環境をも統合 的に設計し運営する視点が必要である。

\section{5. まとめ}

植物葉分光スペクトル特性におよぼすカロテノイ ド組成の影響について, 薄層クロマトグラフィ (TLC)による定性組成から述べた。5樹種の緑葉の 主要なカロテノイド組成は, カロテン類, ルテイン, ヴィオラキサンチン，ネオキサンチンであり，高等 植物のカロテノイド組成の共通性が確認された。黄 葉・紅葉ではカロテノイド量の減少とともにその組 成は変動し，植物葉カロテノイド組成が環境応答的 に生理生態的な変化をすることが示唆された。植物 葉の分光スペクトルにおいて, 可視・青領域は, 植 物種によらず, また, 緑葉, 黄葉・紅葉さらには枯 葉についてもカロテノイドが関与する吸収領域であ り, 以下のような応用展開が考えられる。

1. カロテノイドが関与する植物葉の可視・青領域 の低い反射の共通性は, 今後りモートセンシング技 術による植生域解析において, 気候帯, 植物群落夕 イプあるいは季節変化にかかわらない植物の同化組 織と同化組織に由来する地表被覆の共通特性として 利用できる可能性がある。

2. 温暖化問題と関連して, 二酸化炭素吸収源とし ての光合成計測技術が求められている。光合成活性 のある植物において, 光条件によってカロテノイド 組成が変換するキサントフィル・サイクル色素は, 組成変化にともなう分光反射スペクトルシフトを遠 隔探査でき, 光合成活性指標となる植生パラメー夕 とされている ${ }^{14)}$ 。

3. カロテノイド類による植物葉の可視・青領域光 の選択的な吸収は, 植物葉の反射 - 透過光から青色 光を著しく減少させる。この青領域特性を光環境空 間設計の基礎データとして考え，スペクトル特性を いかした緑化の設計と運営により, 過剩な青色光環 境を緩和する機能性空間を創出することができ $3^{17,19)}$ 。

本報告は, 平成 11 年度〜平成 12 年度 (平成 11 年
8 月 31 日，退職により廃止）科学研究費補助金（基 盤研究 (C) (2); 課題番号：11650553）「紫外線環境 緩和の機能の視点から考える地域特性のある都市緑 化の景観設計と管理」の研究成果の一部である。

\section{引用文献}

1) Briggs, D. E.: Barley. Chapman \& Hall Ltd., London, 612 pp., 1978

2) Francis, G. W. and Isaksen, M.: Thin-layer chromatography of carotenoids with tertiary alcohol-petroleum ether solutions as developing solvents. J. Food Sci., 53(3), 979-980, 1988

3) Gamon, J. A., Peñuelas, J. and Field, C. B.: A narrow-waveband spectral index that tracks diurnal changes in photosynthetic efficiency. Remote Sens. Environ., 41, 35-44, 1992

4) Goodwin, T. W.: Studies in carotenogenesis. The changes in carotenoid and chlorophyll pigments in the leaves of deciduous trees during autumn necrosis. Biochem. J., 68, 503-511, 1958

5) Goodwin, T. W.: Chemistry and biochemistry of plant pigments. Academic Press, London, New York, 583 pp., 1964

6) Harborne, J. B.: Phytochemical methods, 2nd ed. Chapman and Hall, London, New York, 288 pp., 1984

7）林 孝三: 植物色素, 養賢堂, 647 pp., 1988

8) IDA, K.: Eco-physiological studies on the response of Taxodiaceous conifers to shading, with special reference to the behaviour of leaf pigments. I. Distribution of carotenoids in green and autumnal reddish brown leaves of gymnosperms. Bot. Mag. Tokyo, 94, 41-54, 1981

9) Ida, K., Masamoto, K., Maoka, T., Fujiwara, Y., TAKEDA, S. and Hasegawa, E.: The leaves of the common box, Buxus sempervirens (Buxaceae), become red as the level of a red carotenoid, anhydroeschscholtzxantin, increases. J. Plant Res., 108, 369-376, 1995

10) Lichtenthaler, H. K.: Light-stimulated synthesis of plastid quinones and pigments in etiolated barley seedlings. Biochim. Biophys. Acta, 184, 164-172, 1969

11) Lichtenthaler, H. K.: Chlorophylls and carotenoids: Pigments of photosynthetic biomembranes. Methods in Enzymology, 148, 350-382, 1987

12) Odum, E. P.: Fundamentals of ecology, 3rd ed. W. B. Saunders Co., Philadelphia, London, Toronto, 574 pp., 1971

13）朴 慶培・佐藤 庚: 水稲幼植物の葉身の色素分離 法について，日作紀，50(2)，239-240，1981

14）六川修一, 山形与志樹, 土田 聡, 小熊宏之, 関根 
秀真：温室効果ガス削減問題における今後のりモ ートセンシングの役割, 日本リモートセンシング学 会第 25 回学術講演会, A29, 77-80, 1998

15） SAnger, J. E.: Quantitative investigations of leaf pigments from their inception in buds through autumn coloration to decomposition in falling leaves. Ecology, 52(6), 1075-1089, 1971

16) Shiraki, M., Yoshimura, M. and Iriyama, K.: Rapid and easy separation of chlorophylls, their derivatives, and plant yellow pigments by thinlayer chromatography. Chem. Letts., 73, 103-104, 1978

17）吉村晴佳：植物葉の紫外域分光スペクトル特性の
季節性, 日本リモートセンシング学会 第 22 回学 術講演会論文集，B17，125-128，1997

18）吉村晴佳：葉齢による樹葉の近赤外域分光特性と 重なりの効果, 日本りモートセンシング学会誌, 18 (1)，42-56，1998

19）吉村晴佳：都市の有害紫外線環境の緩和に関する 緑化の機能の理論的研究, 平成 9 年度〜平成 10 年 度文部省科学研究費補助金（基盤研究 (C) (2)）（課 題番号：09650594）研究成果報告書, 1999

20）吉村晴佳・石田雅士・小橋澄治・大手桂二：樹葉の 季節的可視域分光特性変化におよぼす植物色素の 影響，日本緑化工学会誌，20(2)，99-110，1994

(1999. 1. 9 受理)

\section{Summary}

The relationship between spectral properties of tree leaves and components of carotenoids is discussed by the results of absorption spectrum and thin-layer chromatography (TLC). The technical applications are also referred. The results of thin-layer chromatography from five different species showed that photosynthetically active green leaves include carotenes, lutein, violaxanthin and neoxanthin as major components. The components of carotenoids altered in yellow leaves and red leaves of deciduous trees during autumn coloration. Carotenes and lutein were observed with traces of violaxanthin and neoxanthin. Reflectance in the visible blue region with various physiological states of leaves, photosynthetically active green, autumn senescence and falling dead, was low by absorption of carotenoids. Only in photosynthetically active leaves, excessive absorbed light causes deepoxidation of the xanthophyll violaxanthin. The difference spectrum associated with conversions of the xanthophyll cycle pigments results in a detectable shift in the leaf reflectance. Using functions of leaf spectral properties in the visible blue region, spatial planning involving trees and plants would abate the overabundant blue light environment harmful to our eyes. From the viewpoint of monitoring terrestrial vegetation in remote sensing, the blue band would be useful for discriminating vegetative cover. 